\title{
Efek Hepatotoksisitas Ekstrak Etanol Herba Kompri (Symphytum officinale L.) Terhadap Hewan Uji Kelinci (Oryctolagus cuniculus) Dengan Parameter SGOT dan SGPT
}

\author{
NORMA $^{1}$, ULFA TRIYANI A. LATIF ${ }^{2}$, SYAMSIDAR USMAN $^{1}$ \\ ${ }^{1}$ Fakultas Farmasi, Universitas Indonesia Timur \\ Jl. Rappocini Raya 171 Makassar 90222 \\ email: norma@gmail.com \\ ${ }^{2}$ Jurusan Biologi, Fakultas Sains dan Teknologi, UIN Alauddin Makassar \\ Jl. Sultan Alauddin 36 Samata, Kab. Gowa 92113 \\ email: ulfatriyani@uin-alauddin.ac.id
}

\begin{abstract}
This study aims to determine the hepatotoxic effects of extract ethanol Herba Comfrey the rabbit test animals by measuring levels of SGOT and SGPT. This study used 12 rabbits were divided into 4 groups. The control group (-) given Na.CMC 1\% w/v, group I, II, and III were given suspensions of extract ethanol Herba Comfrey with each concentration of $2 \% \mathrm{w} / \mathrm{v}, 4 \% \mathrm{w} / \mathrm{v}$ and $8 \% \mathrm{w} / \mathrm{v}$ for 7 days. The results showed that the extract ethanol Herba Comfrey with concentration of $2 \% \mathrm{w} / \mathrm{v}, 4 \% \mathrm{w} / \mathrm{v}$, and $8 \% \mathrm{w} / \mathrm{v}$ effects can cause hepatotoxicity. It is showed from the increase in the average SGOT value in rabbits at $13.96 \mathrm{U} / \mathrm{L}, 20.63 \mathrm{U} / \mathrm{L}$ and $37.13 \mathrm{U} / \mathrm{L}$. and SGPT value of $20.73 \mathrm{U} / \mathrm{L}, 32.4 \mathrm{U} / \mathrm{L}$ and $44.66 \mathrm{U} / \mathrm{L}$. extract Ethanol Herba Comfrey with concentration $8 \% \mathrm{w} / \mathrm{v}$ causes an increase in SGOT and SGPT concentrations higher than the other, and accelerate the liver damage or hepatotoxicity. The higher the concentration, the greater the effect.
\end{abstract}

Keywords: Herba Comfrey, hepatotoxicity, SGOT-SGPT

\section{PENDAHULUAN}

Keberadaan tanaman sebagai obat sudah dikenal sejak ribuan tahun lampau. Bukti sejarah ini terukir di helaian lontar, dindingdinding candi, dan kitab masa lalu. Resep diwariskan turun-temurun, yang tadinya hanya dikenal kalangan tertentu kemudian menyebar hingga masyarakat luas. Dunia mencatat tradisi herbal berkembang pesat di dunia timur. Modernisasi menautkan tanaman obat dengan dunia farmasi. Perlahan-lahan keampuhannya diakui kalangan ilmiah. Walaupun begitu, pemakaian obat tradisional tetap mendapat tempat dengan langkah dan cara pengolahan yang benar, khasiat tanaman obat tidak akan berubah. Salah satu tanaman yang digunakan sebagai obat tradisional adalah Kompri (Symphytum officinale L) dari family Boraginaceae. Kompri sudah terkenal di negara-negara Eropa. Daunnya dibuat teh herbal, akarnya dibuat serbuk dan dikapsulkan. Kompri digunakan untuk menurunkan gula darah, menormalkan hipertensi, radang sendi, diare, radang usus, gangguan pencernaan, pegal linu, batuk berdahak, amandel, dan wasir. Selain itu kompri juga diketahui berkhasiat untuk menurunkan kadar kolesterol dalam darah, meningkatkan hemoglobin yang rendah, mengatasi pneumonia, batu ginjal, ambeien, kemandulan pada wanita, asma, gangguan empedu, tumor, kanker, patah tulang, luka dan alergi kulit (Murti dan Poerba, 2010).

Biasanya daun kompri digunakan dengan cara merebus daun yang sudah agak tua baik dalam keadaan segar maupun yang sudah dikeringkan atau dengan cara menggiling halus daun segar kemudian diperas. Selain digunakan sebagai obat, daun muda dari tanaman ini biasa dimakan sebagai sayuran (Asmita, 2007).

Beberapa penelitian sebelumnya, salah satunya dilakukan oleh Amrizal pada tahun 1988 (dalam buku Dalimartha, 2007) tentang Uji Efek Infus Daun Kompri (Symphytum officinale L) Terhadap Kadar Glukosa Darah Tikus Putih Jantan, hasilnya menunjukkan infus daun kompri 20\% dengan takaran 25 dan 
$40 \mathrm{ml} / \mathrm{kg}$ BB mempunyai efek menurunkan kadar gula darah tikus putih jantan sebanding dengan suspensi klorpropamida $22,5 \mathrm{mg} / \mathrm{kg}$ BB.

Asmita (2007) telah melakukan penelitian tentang Uji Efek Teratogenik Infus Daun Kompri (Symphytum officinale L) pada Mencit Putih Betina, hasilnya menunjukkan infus 20\% daun kompri pada dosis 12,$5 ; 25$, dan $50 \mathrm{ml} / \mathrm{kg}$ BB tidak menimbulkan efek teratogenik pada fetus mencit namun dosis $50 \mathrm{ml} / \mathrm{kg} \mathrm{BB}$ dapat menyebabkan keguguran pada induk mencit.

Selain itu, telah dilakukan penelitian pengaruh infus Daun Kompri terhadap efek menurunkan tekanan darah pada anjing dan kontraksi jantung pada katak. Penelitian tersebut menghasilkan beberapa kesimpulan antara lain: yang pertama bahwa infus daun kompri $10 \%$ dengan takaran $0,5 \mathrm{cc} / \mathrm{kg} \mathrm{BB}$ diberikan secara intra vena mempunyai pengaruh menurunkan tekanan darah, dan yang kedua bahwa infus daun kompri 2,5\% $\mathrm{b} / \mathrm{v}, 5 \% \mathrm{~b} / \mathrm{v}, 10 \% \mathrm{~b} / \mathrm{v}$ dan $20 \% \mathrm{~b} / \mathrm{v}$ mempunyai pengaruh menghambat kontraksi jantung (Runadi, 2007).

Umumnya masyarakat menganggap bahwa obat tradisional yang biasanya digunakan tidak dapat menimbulkan keracunan. Tapi karena obat tradisional juga mengandung zat-zat kimia, maka toksisitas juga bisa terjadi. Apalagi jika bahan tersebut digunakan dalam waktu panjang berkemungkinan bisa menyebabkan toksisitas kronis dan menimbulkan efek karsinogenitas, dan mutagenitas (Asmita, 2007).

Herba Kompri mengandung senyawa alkaloid pyrrolizidine yang diketahui penyebab utama kerusakan hati yang dinamakan hepatic veno-occlusive disease (HVOD), apabila pemakaian berlebihan dapat menyebabkan keracunan terutama kerusakan hati (hepatotoksik) (Dalimartha, 2007).

Tujuan penelitian ini untuk mengetahui efek hepatotoksik ekstrak etanol Herba Kompri pada hewan uji kelinci berdasarkan pengukuran kadar SGOT dan SGPT. Penelitian ini dapat dimanfaatkan sebagai acuan penggunaan Herba Kompri untuk obat tradisional, sehingga efek terapi yang diinginkan dapat tercapai dan efek toksiknya dapat dihindari.

\section{METODE}

Pengambilan Sampel. Herba Kompri diambil mulai dari akar hingga daun pada pagi hari sekitar pukul 08:00 - 10:00 WITA.

Pengolahan Sampel. Herba Kompri dicuci dengan air mengalir lalu dianginanginkan. Setelah itu dipotong-potong kecil dalam bentuk rajangan dan diangin-anginkan pada suhu kamar hingga kering.

Pembuatan Ekstrak Etanol Herba Kompri. Herba Kompri dalam bentuk rajangan ditimbang sebanyak $700 \mathrm{~g}$, lalu dimasukkan ke dalam bejana maserasi kemudian direndam dengan etanol $70 \%$ dan dilakukan pengadukan dua kali sehari. Ekstraksi dengan metode maserasi dilakukan selama 5 hari, setelah itu ekstrak cair yang dihasilkan diuapkan dengan menggunakan alat penguap bertekanan Rotavapor sehingga diperoleh ekstrak etanol Herba Kompri.

Pembuatan Larutan Pensuspensi Na.CMC 1\% b/v. Ditimbang serbuk Na.CMC sebanyak 1 gram kemudian dilarutkan dengan $50 \mathrm{ml}$ aquadest yang telah dipanaskan dan diaduk hingga homogen, lalu dimasukkan ke dalam labu tentukur, dicukupkan volumenya dengan aquadest hingga $100 \mathrm{ml}$.

Penyiapan Suspensi Ekstrak Etanol Herba Kompri. Suspensi ekstrak etanol Herba Kompri dibuat dengan menambahkan larutan pensuspensi Na.CMC 1\% b/v. Konsentrasi ekstrak etanol Herba Kompri yang dibuat adalah $2 \% \mathrm{~b} / \mathrm{v}, 4 \% \mathrm{~b} / \mathrm{v}$ dan $8 \% \mathrm{~b} / \mathrm{v}$. Suspensi ekstrak etanol Herba Kompri 2\% dibuat dengan menimbang 2 gram ekstrak etanol Herba Kompri lalu dimasukkan ke dalam gelas kimia $100 \mathrm{ml}$ kemudian disuspensikan dengan larutan pensuspensi $\mathrm{Na.CMC} \mathrm{1 \%} \mathrm{b/v} 50 \mathrm{ml}$ dan dihomogenkan. Setelah homogen, dimasukkan ke dalam labu tentukur $100 \mathrm{ml}$ dan dicukupkan volumenya hingga tanda batas. Cara yang sama dilakukan untuk membuat suspensi ekstrak etanol Herba Kompri 4\% b/v dan 8\% b/v. Ekstrak etanol Herba Kompri ditimbang masing-masing adalah 4 gram dan 8 gram. 
Perlakuan Terhadap Hewan Uji. Disiapkan hewan uji kelinci yang berbadan sehat sebanyak 12 ekor. Dipuasakan selama 68 jam, ditimbang dan dikelompokkan berdasarkan berat badan. Diambil darah kelinci dan dilakukan pengukuran nilai SGOT dan SGPT awal. Kelinci diberi perlakuan: Kontrol negatif: Diberikan suspensi Na.CMC $1 \%$ b/v. Kelompok I: Diberi suspensi ekstrak etanol Herba Kompri konsentrasi $2 \%$ b/v. Kelompok II: Diberi suspensi ekstrak etanol Herba Kompri konsentrasi 4\% b/v. Kelompok III: Diberi suspensi ekstrak etanol Herba Kompri konsentrasi $8 \%$ b/v. Pemberian suspensi dilakukan selama 7 hari berturutturut. Pada hari ke-8 dilakukan pengukuran nilai SGOT dan SGPT akhir menggunakan Fotometer.

\section{Cara Pengambilan Sampel Darah}

Hewan Uji. Pengambilan sampel darah kelinci dilakukan pada bagian telinga, dimana terdapat vena marginalis. Adapun langkah awal yaitu dibersihkan rambut-rambut pada daerah telinga sampai bersih dengan menggunakan silet sampai terlihat vena marginalisnya, kemudian diusapkan kapas yang telah dibasahi alkohol dengan tujuan agar vena yang kecil menjadi besar untuk mempermudah dalam pengambilan darah. Pengambilan darah dilakukan dengan menggunakan spoit insulin 1 cc dan darah dimasukkan ke dalam tabung vacutainer kemudian disentrifug. Tujuan dilakukannya sentrifug yaitu untuk memisahkan serum dan plasma darah.

Pengumpulan dan Analisis Data. Data yang diperoleh dari hasil pengukuran SGOT dan SGPT awal, setelah pemberian ekstrak etanol Herba Kompri dan setelah pemberian suspensi Na.CMC $1 \%$ b/v sebagai kontrol, kemudian dianalisis secara statistik menggunakan analisis varians dari Rancangan Acak Lengkap (RAL).

\section{HASIL}

Tabel 1. Hasil pemeriksaan nilai SGOT sebelum dan sesudah pemberian Na.CMC 1\% dan Ekstrak Etanol Herba Kompri pada Hewan Uji Kelinci

\begin{tabular}{|c|c|c|c|c|}
\hline Perlakuan & $\mathrm{N}$ & Nilai SGOT Awal & $\begin{array}{l}\text { Nilai SGOT setelah } \\
\text { Perlakuan }\end{array}$ & $\begin{array}{l}\text { Jumlah } \\
\text { Peningkatan }\end{array}$ \\
\hline \multirow{4}{*}{$\begin{array}{l}\text { Kontrol (-) } \\
(\text { Na.CMC } 1 \% \text { b/v) }\end{array}$} & 1 & 36,1 & 37,2 & 1,1 \\
\hline & 2 & 31,5 & 32,7 & 1,2 \\
\hline & 3 & 35,1 & 36,6 & 1,5 \\
\hline & $\mathrm{X}$ & 34,23 & 35,43 & 1,26 \\
\hline \multirow{4}{*}{$\begin{array}{l}\text { Ekstrak Etanol Herba Kompri } \\
2 \% \mathrm{~b} / \mathrm{v}\end{array}$} & 1 & 32,4 & 46,3 & 13,9 \\
\hline & 2 & 35,3 & 49,7 & 14,4 \\
\hline & 3 & 33,8 & 47,4 & 13.6 \\
\hline & X & 33,83 & 47,8 & 13,96 \\
\hline \multirow{4}{*}{$\begin{array}{l}\text { Ekstrak Etanol Herba Kompri } \\
4 \% \mathrm{~b} / \mathrm{v}\end{array}$} & 1 & 36,9 & 58,4 & 21,5 \\
\hline & 2 & 32,1 & 53,3 & 21,2 \\
\hline & 3 & 31,5 & 50,7 & 19,2 \\
\hline & $\mathrm{X}$ & 33,5 & 54,13 & 20,63 \\
\hline \multirow{4}{*}{$\begin{array}{l}\text { Ekstrak Etanol Herba Kompri } \\
8 \% \mathrm{~b} / \mathrm{v}\end{array}$} & 1 & 31,2 & 68,4 & 37,2 \\
\hline & 2 & 34,6 & 70,6 & 36 \\
\hline & 3 & 33,1 & 71,3 & 38,2 \\
\hline & $X$ & 32,96 & 70,1 & 37,13 \\
\hline
\end{tabular}

Tabel 2. Hasil pemeriksaan nilai SGPT sebelum dan sesudah pemberian Na.CMC 1\% dan Ekstrak Etanol Herba Kompri pada Hewan Uji Kelinci

\begin{tabular}{lcccc}
\hline Perlakuan & $\mathrm{N}$ & Nilai SGPT Awal & $\begin{array}{l}\text { Nilai SGPT setelah } \\
\text { Perlakuan }\end{array}$ & $\begin{array}{l}\text { Jumlah } \\
\text { Peningkatan }\end{array}$ \\
\hline Kontrol $(-)$ & 1 & 36,7 & 38,4 & 1,7 \\
(Na.CMC 1\% b/v) & 2 & 38,5 & 40,6 & 2,1 \\
& 3 & 39,4 & 41,9 & 2,5 \\
\hline & $\mathrm{X}$ & 38,2 & 40,3 & 2,1 \\
\hline
\end{tabular}




\begin{tabular}{lllcc}
\hline Ekstrak Etanol Herba Kompri & 1 & 37,4 & 59,6 & 22,2 \\
\cline { 2 - 5 } $2 \% \mathrm{~b} / \mathrm{v}$ & 2 & 37,9 & 58,4 & 20,5 \\
\cline { 2 - 5 } & 3 & 35,8 & 55,3 & 19,5 \\
\cline { 2 - 5 } & $\mathrm{X}$ & 37,03 & 57,76 & 20,73 \\
\hline Ekstrak Etanol Herba Kompri & 1 & 36,3 & 68,9 & 32,6 \\
\cline { 2 - 5 } $4 \% \mathrm{~b} / \mathrm{v}$ & 2 & 38,4 & 70,1 & 31,7 \\
\cline { 2 - 5 } & 3 & 35,8 & 68,7 & 32,9 \\
\hline Ekstrak Etanol Herba Kompri & $\mathrm{X}$ & 36,83 & 69,23 & 44 \\
\hline 8\% b/v & 2 & 35,8 & 89,8 & 44,2 \\
& 2 & 39,4 & 83,6 & 45,8 \\
\hline & 3 & 34,6 & 81,26 & 44,66 \\
\hline
\end{tabular}

\section{PEMBAHASAN}

Serum Glutamic Oxaloacetic Transminase (SGOT) dan Serum Glutamic Pyruvic Transminase (SGPT) merupakan enzim intra seluler yang dalam keadaan normal seharusnya berada di dalam sel. Keduanya merupakan enzim transaminase yang berfungsi mengkatalis reaksi kimia yang terjadi dalam sel. Apabila terdapat senyawa-senyawa toksik pada sel hati, maka akan terjadi perubahan permeabilitas pada membran sel. Sehingga enzim-enzim yang seharusnya berada di dalam sel akhirnya keluar dari dalam sel dan berada dalam darah.

Pada penelitian ini dilakukan 2 kali pengukuran SGOT dan SGPT darah yaitu pengukuran kadar SGOT dan SGPT awal sebelum perlakuan, hal ini dilakukan untuk mengetahui kadar awal SGOT dan SGPT. Pengukuran kedua, dilakukan pengukuran kadar SGOT dan SGPT setelah 7 hari perlakuan, pada kelompok control (-) diberikan Na.CMC 1\% b/v, pada kelompok I, II, dan III masing-masing diberikan ekstrak etanol Herba Kompri dengan konsentrasi 2\% $\mathrm{b} / \mathrm{v}, 4 \% \mathrm{~b} / \mathrm{v}$, dan $8 \% \mathrm{~b} / \mathrm{v}$.

Berdasarkan hasil penelitian, setelah hewan uji diberikan Na.CMC $1 \%$ b/v tidak menunjukkan terjadinya peningkatan kadar SGOT dan SGPT, hal ini menunjukkan bahwa $\mathrm{Na} . \mathrm{CMC} 1 \% \mathrm{~b} / \mathrm{v}$ tidak mempunyai pengaruh terhadap kadar SGOT dan SGPT. Sedangkan pada tiap kelompok perlakuan, pemberian suspensi ekstrak etanol Herba Kompri $2 \%$ b/v, $4 \% \mathrm{~b} / \mathrm{v}$ dan $8 \% \mathrm{~b} / \mathrm{v}$ selama 7 hari berturut-turut didapatkan rata-rata jumlah peningkatan kadar SGOT sebesar 13,96 U/L, 20,63 U/L dan $37,13 \mathrm{U} / \mathrm{L}$. Sedangkan rata-rata jumlah peningkatan kadar SGPT sebesar 20,73 U/L, 32,4 U/L dan 44,66 U/L.

Dari uji statistik ANOVA dengan menggunakan metode Rancangan Acak Lengkap didapatkan hasil bahwa $\mathrm{Fh}>\mathrm{Ft}$. untuk pemeriksaan SGOT didapatkan nilai yaitu 904,59 > 4,07 (pada taraf $\alpha_{0,05}$ ) dan $904,59>7,59$ (pada taraf $\alpha_{0,01}$ ). Sedangkan pada pemeriksaan SGPT didapatkan nilai yaitu $1.171,54>4,07$ (pada taraf $\alpha_{0,05}$ ) dan 1.171,54 $>4,07$ (pada taraf $\left.\alpha_{0,01}\right) . H_{0}$ ditolak, Hipotesa satu $\left(\mathrm{H}_{1}\right)$ diterima, yang menunjukkan ada efek hepatotoksisitas ekstrak etanol Herba Kompri terhadap hewan uji kelinci dengan parameter SGOT dan SGPT. Dimana semakin tinggi konsentrasi ekstrak etanol Herba Kompri maka semakin besar jumlah peningkatan nilai SGOT maupun SGPT. Hal ini didukung oleh uji Newman-Keuls yang menunjukkan terjadi perbedaan secara signifikan antara tiap perlakuan.

Pemberian suspensi ekstrak etanol Herba Kompri dengan konsentrasi $8 \% \mathrm{~b} / \mathrm{v}$ dapat menyebabkan peningkatan kadar SGOT dan SGPT dua kali lipat dari nilai awalnya. Hal ini menunjukkan bahwa penggunaan Herba Kompri secara berlebihan dapat menimbulkan efek kerusakan hati atau hepatotoksik pada hewan uji kelinci, dan tidak menutup kemungkinan Herba Kompri juga dapat menyebabkan kerusakan hati pada manusia.

Menurut Dalimartha (2007), Herba Kompri mengandung beberapa zat berkhasiat seperti symphytine, tanin, allantoin, dan beberapa vitamin seperti vitamin B1, B2, C dan vitamin E. Selain itu, Herba Kompri juga mengandung alkaloid pyrrolizidine, dimana akar mengandung alkaloid pyrrolizidine 
dengan jumlah yang lebih besar dari daun. Alkaloid pyrrolizidine diketahui merupakan penyebab utama kerusakan hati yang dinamakan hepatic veno-occlusive (HVOD), yang apabila digunakan secara berlebihan dan terus menerus dapat menyebabkan keracunan terutama kerusakan hati atau hepatotoksik.

\section{KESIMPULAN}

1. Ekstrak etanol Herba Kompri dengan konsentrasi $2 \% \mathrm{~b} / \mathrm{v}, 4 \% \mathrm{~b} / \mathrm{v}$, dan $8 \% \mathrm{~b} / \mathrm{v}$ dapat menimbulkan efek hepatotoksisitas. Hal ini ditunjukkan dari adanya kenaikan nilai rata-rata SGOT dan SGPT pada kelinci.

2. Ekstrak etanol Herba Kompri dengan konsentrasi $8 \% \quad \mathrm{~b} / \mathrm{v}$ menyebabkan kenaikan nilai SGOT dan SGPT lebih tinggi dibanding konsentrasi lainnya, dan mempercepat kerusakan hati atau Hepatotoksik.

3. Semakin tinggi konsentrasi maka semakin tinggi efek yang ditimbulkan.

\section{DAFTAR PUSTAKA}

Asmita L. 2007. Uji Efek Teratogenik Infus Daun Kompri (Symphytum officinale Linn) Pada Mencit Putih Betina. [Skripsi]. Padang: FMIPA Universitas Andalas. hal 1, 2, 36 .

Baradero M, Dayrit MW, dan Siswadi Y. 2008. Seri Asuhan Keperawatan Klien Gangguan Hati. Jakarta: Penerbit Buku Kedokteran EGC. hal 5 - 9.

Bastiansyah E. 2008. Panduan Lengkap Membaca Hasil Tes Kesehatan. Jakarta: Penebar Plus. hal 53 - 55.

Dalimartha S. 2007. Atlas Tumbuhan Indonesia. Jakarta: Trubus Agriwidya. hal $78-81$.

Departemen Kesehatan. 1979. Farmakope Indonesia. Jakarta: Direktorat Jendral Pengawasan Obat dan Makanan. hal 65.
Departemen Kesehatan. 1986. Sediaan Galenika. Jakarta: Direktorat Jendral Pengawasan Obat dan Makanan. hal. 4 30.

Malole MBM, dan Pramono CSU. 1989. Penggunaan Hewan - Hewan Percobaan di Laboratorium. Bogor: Departemen Pendidikan dan Kebudayaan Direktorat Jendreral Pendidikan Tinggi Pusat Antar Universitas Bioteknologi Institut Pertanian Bogor. hal $62-65$.

Mitchell, Kumar, Abbas, dan Fausto. 2006. Buku Saku Dasar Patologis Penyakit. Robbins \& Cotran Edisi 7. Terjemahan oleh Hartono, A. 2009. Jakarta: Penerbit Buku Kedokteran EGC. hal 509-515.

Murti TK, dan Poerba AP. 2010. 101 Ramuan Tradisional Untuk Mengatasi Berbagai Penyakit. Yogyakarta: Insania. hal. 54.

Pearce EC. 2008. Anatomi dan Fisiologi untuk Paramedis. Jakarta: PT Gramedia Pustaka Utama, hal. $201-206$.

Runadi D. 2007. Isolasi dan Identifikasi Alkaloid dari Herba Komfrey (Symphytum officinale L.). Karya Ilmiah Penelitian yang Tidak Dipublikasikan. Jatinangor: Fakultas Farmasi Universitas Padjadjaran. hal 2.

Sari W, Indrawati L, dan Djing OG. 2008. Care Yourself Hepatitis. Jakarta: Penebar Plus. hal 28, 30.

Sloane E. 1994. Anatomi dan Fisiologi Untuk Pemula. Terjemahan oleh Widyastuti, P. 2004. Jakarta: Penerbit Buku Kedokteran EGC. hal 291.

Smith B, John VSc, dan Mankoewidjojo S. 1988. Pemeliharaan, Pembiakan dan Penggunaan Hewan Percobaan di Daerah Tropis. Jakarta: Universitas Indonesia Press. hal 54.

Wijayakusuma HMH. 2008. Tumpas Hepatitis dengan Ramuan Herbal. Jakarta: Pustaka Bunda. hal 1-2. 